\title{
Australian Journal of \\ Crop Science \\ Natural resistance of two mango Mangifera indica L. commercial cultivars to anthracnose caused by Colletotrichum gloeosporioides Penz. Penz. \& Sacc
}

\author{
A. Sánchez-Arizpe ${ }^{1}$, Ma. E. Galindo-Cepeda ${ }^{1}$, J. L. Arispe-Vázquez ${ }^{1 *}$, R. Genis-Velázquez ${ }^{1}$, M. E. Vázquez- \\ Badillo $^{2}$, A. Antonio-Bautista ${ }^{2}$ \\ ${ }^{1}$ Departamento de Parasitología, Universidad Autónoma Agraria Antonio Narro, Calzada Antonio Narro \#1923, C.P. \\ 25315, Buenavista, Saltillo, Coahuila, México \\ ${ }^{2}$ Departamento de Fitomejoramiento, Universidad Autónoma Agraria Antonio Narro, Calzada Antonio Narro \#1923, \\ C.P. 25315, Buenavista, Saltillo, Coahuila, México
}

*Corresponding author: arispe_uaaan@hotmail.com

\begin{abstract}
Mexico ranks first worldwide as the largest mango exporter is one of the more produced tropical fruits worldwide. The need for strategies for the protection of crops, environment and people leads us to investigate disease control methods. The use of resistant cultivars is the most important. In addition, it is advantageous for the producer because it will reduce the cost for disease control. The objective of this research was to evaluate the natural resistance of two mango cultivars against anthracnose, using different spore doses and times of evaluation. The sampling was performed on April 15 ${ }^{\text {th }}, 2018$ at an open market placed south of Saltillo, Coahuila, Mexico. Pathogen was isolated from fruits of Tommy Atkins and Ataulfo mango cultivars showing advanced degrees of black spots collected out from at open markets in Saltillo, Coahuila, Mexico. The pathogen purification was done by monoconidial cultures and identification was done with morphocultural criteria. Spore suspension was prepared and inoculated on ripe mango fruits using different doses and disease severity was evaluated 6 and 10 days after inoculation using millimetric sheets. A complete random factorial design of three factors was used, where: factor A stands for mango cultivars (Tommy Atkins and Ataulfo), factor B is treatments and factor $C$ stands for times of evaluation. The results are shown as percentage and data was analyzed with factorial analysis using the SAS 9.1 software. C. gloeosporioides was identified in mango cultivars; with hyaline conidia of 16.90 to $25.12 \mu \mathrm{m}$ length and 4.33 to $5.18 \mu \mathrm{m}$ width. The results show cultivars resistant to anthracnose in the study area. Natural resistance against anthracnose was as 80.00 to $93.67 \%$, thus, mango cultivars showed a certain resistant degree.
\end{abstract}

Keywords: Doses, incidence, severity, \% of damage, crop.

Introduction

Mango Mangifera indica L. is one of the more produced tropical fruits worldwide. It is also known as the 'King of fruits' (Purnachandra and Saritha, 2013) belonging to the Anacardiaceae family (Nawab et al., 2017). Colletotrichum Corda corresponds to genus of phytopathogenic fungi that causes diseases and mainly anthracnose in different hosts. The genus Colletotrichum consists of approximately 600 species including most studied species like Colletotrichum gloeosporioides (Penz.) Penz. \& Sacc., Colletotrichum capsici (Schweinitz) Andrus \& W. D. Moore, Colletotrichum acutatum J.H. Simmonds, Colletotrichum dematium (Persoon) Grove, Colletotrichum nigrum Ellis \& Halsted and Colletotrichum coccodes (Wallroth) S. J. Hughes (Glomerellaceae). The species of this genus infect more than 3200 species of monocot and dicot plants ( $O^{\prime}$ Connell et al., 2012).

Anthracnose caused by these fungal pathogens can negatively impact both yield and fruit quality in post-harvest (Sutton, 1980; Arauz, 2000). This disease is more serious in all mango growing regions of the world (Smooth and Segall,
1963; Tandon and Singh, 1968; Muirhead and Grattidge, 1984; Johnson et al., 1989). The anthracnose caused by $C$. gloeosporioides reduces the shelf life of mature fruit (Wu et al., 2020; Ahmad et al., 2021). This pathogen belongs to the Family: Glomerellaceae; Order: Glomerellales, Class: Sordariomycetes, Phylum: Ascomycota and Kingdom: Fungi (Chen et al., 2015). Also, it manifests itself as dark brown or black spots, which grow and form larger and more cleft ones (Sangeetha and Rawal, 2008). One species of this fungi is Glomerella cingulate (Stoneman) Spauld. \& H. Schrenk (Glomerellaceae), (López-Vásquez and Castaño-Zapata, 2010), which causes the inflorescence to fall, affecting the fruits, leaves and young branches (Álvarez et al., 2006), causing direct and indirect losses (Jeffries et al., 1990; Ploetz, 1994; Prusky et al., 2000).

Production of mango $M$. indica, mangosteens Garcinia mangostana L. (Clusiaceae), and guava Psidium guajava L. (Myrtaceae) during the 2018 cycle was 55,383,785 t worldwide and 2,178,927 $t$ in Mexico. Paez (2003) and Bustamante (2006) showed that losses by anthracnose in 
papaya Carica papaya L. (Caricaceae) and mango ranges between 15 to $50 \%$ up to $60 \%$ (Vega-Piña, 2006; León, 2007). If that $50 \%$ loss during that cycle is taken, $1,089,463.5$ $\mathrm{t}$ was lost in Mexico and 27,691,892.5 $\mathrm{t}$ worldwide. The main growers are India, China and Thailand (FAOSTAT, 2020). The control of Colletotrichum spp. represents a challenge for the farmers, where the preventive protection strategy and the time factor are essential elements given the short incubation period of the fungi and its high sporulation capacity in young tissues (Abd-Alla and Wafaa, 2010). Colletotrichum is a genus of fungi which is a cosmopolitan distribution and predominantly in tropical and subtropical regions (Xiao et al., 2004; Cannon, et al., 2012; Lei, et al., 2016). It was recently voted as the eighth more important group of plant pathogenic fungi in the world, based on perceived scientific and economic importance (Dean et al., 2012).

Identification of Colletotrichum spp. is essential for effective execution strategy as well as genetic improvement programs aiming to manage and control the disease (Than et al., 2008). There is a variation regarding plant susceptibility to either Colletotrichum or Gloeosporium Desmazières \& Montagne (Dermateaceae) and strains of these microorganisms possess different pathogenicity to a given plant (Agrios, 2005). The objective of this research was to evaluate the natural resistance of two cultivars of mango against anthracnose, using different spore doses and times of evaluation.

\section{Results and discussion}

Conidia hyaline and cylindric shape with an average length of 16.90 to $25.12 \mu \mathrm{m}$ and width of 4.33 to $5.18 \mu \mathrm{m}$ were found in a suspension of $2.55 \times 10^{7}$ spores $/ \mathrm{mL}^{-1}$; colonies were white and the mycelium hadving at least $4 \mathrm{~mm}$ height (Table 1). The pathogen possessed acervuli with mushrooms and septate hyphae, distinctive characteristics of $C$. gloeosporioides, similar to those reported by Wharton and Diéguez-Uribeondo, (2004), Tozze et al. (2006), Andrade et al. (2007), Pérez et al. (2003), Muñoz et al. (2003), Montero et al. (2010), Barquero et al. (2013), Trinidad-Ángel et al. (2017). Statistical analysis showed significant difference among factors; cultivars mango (Factor $A, p=0.0012$ ), treatments (Factor B, $p=0.000$ ) and times (Factor C, $p=$ 0.000 ) with a variance coefficient of 21.35 , as well as factor interaction $\mathrm{AXBXC}(p=0.001)$.

Tommy Atkins showed a disease severity of 7.33 to $20.00 \%$, whereas in Ataulfo it was 6.33 to $14.33 \%$ (Table 2, Figure 2). The natural resistance of Tommy Atkins was about 80 to $93.67 \%$ and Ataulfo resistance was 82.67 to $85.67 \%$, where the most severe damage was observed using $3000 \mu \mathrm{L}$ of spore suspension evaluated days 10 after treatment. Ploetz (2008) mentioned that Tommy Atkins variety isresistant to anthracnose, into a certain degree. Using fungicide has a direct control effect, but it is likely to induce resistance in the fungi ( $\mathrm{Hu}$ et al., 2015). Nowadays, the increase in development of resistance to synthetic fungicides, as well as the growing consumer demand for food without pesticides stresses the need for alternative strategies to control phytopathogens (Zhou et al., 2003).

Almada-Ruiz et al. (2003) mentioned that the benomyl in combination with multisite non-mobile protectant fungicides, e.g; mancozeb or copper hydroxide, is currently one of the primary strategies used to control fruit anthracnose preharvest. However, in some cases, their continued use has led to the development of resistance
(Gutiérrez-Alonso et al., 2003). For instance, chemical control of anthracnose requires biweekly or monthly application of fungicides, which could be damaging to the environment, and frequent use of chemical fungicides could lead to the development of fungicide-resistant strains (Onyeka et al., 2006). Ningthoujam et al. (2009) mentioned that the chemical practices to overcome plant disease problem have adverse environmental effects on non-target organisms, causing health hazards to humans, besides demanding high costs. The compulsive use of synthetic fungicides has caused different types of environmental and toxicological problems, such as environmental pollution and health-illness. Therefore, there is a crucial need to find out a sustainable and eco-friendly alternative to address concerned issues (Chung et al., 2006). The integration of a number of practices will reduce or eliminate negative side effects of chemicals being used to control major mango diseases. This is is the most realistic option for solving the problem (Chowdhury and Rahim, 2010). However, the genetic resistance is the only economically viable method of controlling the disease and current research efforts emphasized the search for resistant cultivars (Mignouna et al., 2001). Moreover, sources of inoculum can be avoided by not planting other host plants of postharvest pathogens near to mango crops. This practice eliminates other sources of inoculum such as diseased twigs and diseased fruits (Fittzell and Peak, 1986; Sangchote, 1991).

Low damage severity in mangoes is probably due to the phenological stage of cultivars and ripe mangoes which were used in this study. Villanueva et al. (2006) mentioned that immature fruit of custard apple Annona cherimola Miller (Annonaceae) were more susceptible to Colletotrichum sp. Padron (1991) showed that during the immature stage, mango fruits highly increase its respiratory rate, rendering them more susceptible to disease since most of its strength is channeled to maturation. On the other hand, Bailey and Jeger (1992) reported a high genetic variation among isolates of C. gloeosporioides from avocado Persea Americana Miller (Lauraceae), C. papaya, plantain Musa $x$ paradisiaca L. (Musaceae) and mango. Zainuri et al. (2001) demonstrated that low severity of anthracnose caused by $C$. gloeosporioides in post-harvest mango was due to the presence of salicylic acid, having an average of $0.1-0.25 \mathrm{mg}$ of salicylates every $100 \mathrm{~g}$ of mango (Ngw, 2020).

Valdés et al. (2017) demonstrated that mango cultivars Haden, Bizcochuelo, Delicioso, San Diego, Señora and Macho are susceptible to isolates of $C$. gloeosporioides a $1 \times 10^{5}$ spores $/ \mathrm{mL}^{-1}$ suspension, whereas in this research a $2.55 \times 10^{7}$ spores $/ \mathrm{mL}^{-1}$ suspension was used, which is a difference of $2.54 \times 10^{7}$ spores $/ \mathrm{mL}^{-1}$. On the other hand, Orlando et al. (2013) showed different isolates of $C$. gloeosporioides at $1 \times 10^{6}$ spores $/ \mathrm{mL}^{-1}$ in passion fruit Passiflora edulis Sims (Passifloraceae) crops at 40 days old in the greenhouse reached the maximum disease severity $(70 \%)$ in only 30 days, thus, presented a natural resistance of $30 \%$.

\section{Materials and methods}

\section{Sampling}

The sampling was performed on April $15^{\text {th }}, 2018$ at an open market placed south on Saltillo(Figure 1). Mangoes of Tommy Atkins and Ataulfo cultivars with advanced maturity showing black spots collected out from at open markets in Saltillo, Coahuila, Mexico. Showing the 
Table 1. Conidia means corresponding to C. gloeosporioides.

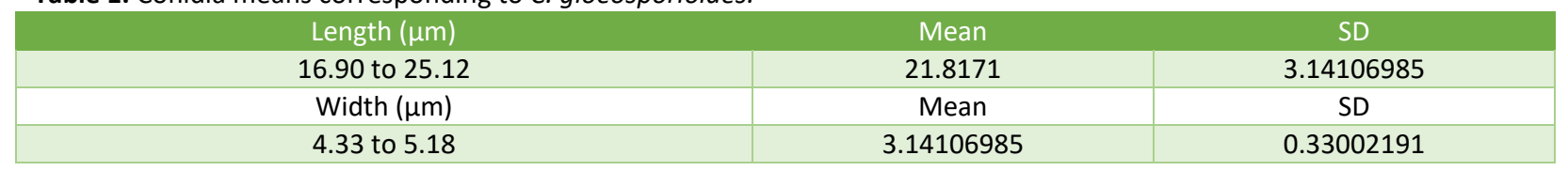

$\mathrm{SD}=$ Standard deviation

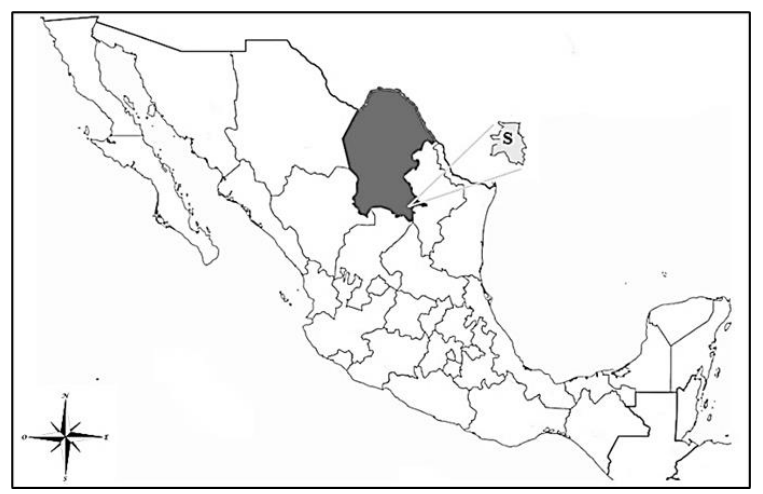

Fig 1. Location of the study area, S=Saltillo, Coahuila, Mexico.

Table 2. Evaluation times of severity of $C$. gloeosporioides in cultivars mango.

\begin{tabular}{|c|c|c|c|c|c|c|}
\hline \multirow{2}{*}{ Cultivar } & Trat. & Sev. (\%) & SD & Trat. & Sev. (\%) & TE 10 \\
\hline Tomy Atkins & 1 & 5.66 & 0.577350269 & 1 & 10.66 & 1.154700538 \\
\cline { 2 - 7 } & 2 & $7.33^{* *}$ & 1.154700538 & 2 & 11.33 & 1.154700538 \\
\cline { 2 - 7 } & 3 & 4.66 & 4.163331999 & 3 & $20.00^{* *}$ & 2.00000000 \\
\hline \multirow{2}{*}{ Ataulfo } & 4 & 0.00 & 0.000000000 & 4 & 0.00 & 0.00000000 \\
\hline & 1 & 4.34 & 0.577350269 & 1 & 8.66 & 1.154700538 \\
\hline & 2 & 5.33 & 1.527525232 & 2 & 11.66 & 1.527525232 \\
\hline & 3 & $6.33^{* *}$ & 1.154700538 & 3 & $14.33^{* *}$ & 1.154700538 \\
\hline
\end{tabular}

TE 6= Evaluation time at six days; TE $10=$ Evaluation time at 10 days; Trat. $=$ Treatments, $1=2.55 \times 10^{7}$ spores $/ \mathrm{mL}^{-1}(1000 \mu \mathrm{L}), 2=2.55 \times 10^{7} \mathrm{spores} / \mathrm{mL}^{-1}(2000 \mu \mathrm{L}), 3=$ $2.55 \times 10^{7}$ spores $/ \mathrm{mL}^{-1}(3000 \mu \mathrm{L})$ and $4=$ Control (sterile water); Sev. $(\%)=\%$ de severity; $\mathrm{SD}=$ Standard deviation. ${ }^{* *}=$ Treatments with higher severity

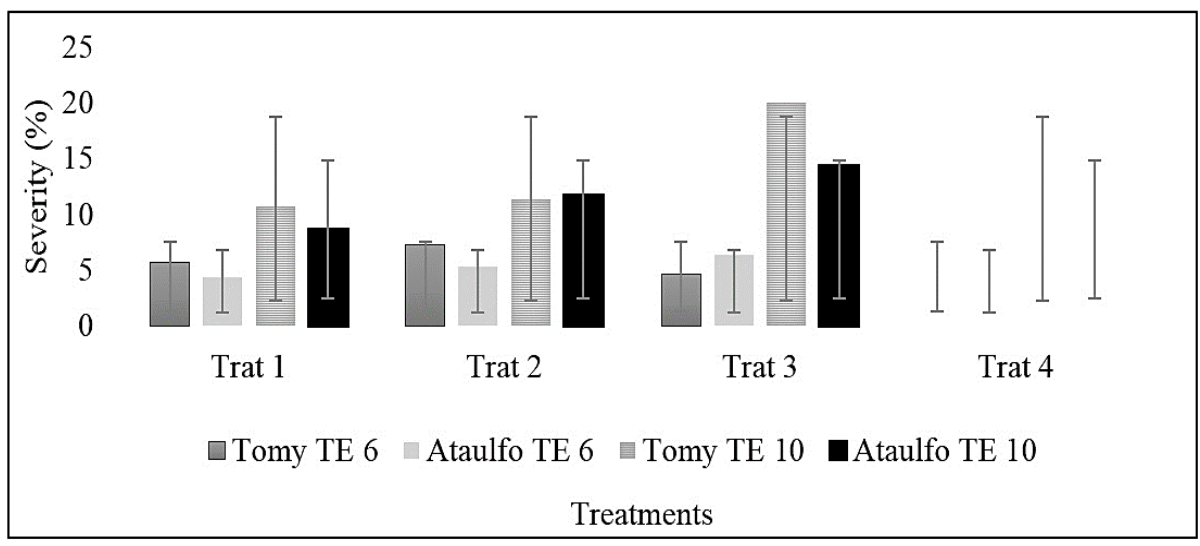

Fig 2. Severity of $C$. gloeosporioides in cultivars mango. Trat $1=2.55 \times 10^{7}$ spores $/ \mathrm{mL}^{-1}(1000 \mu \mathrm{L})$, Trat $2=2.55 \times 10^{7} \mathrm{spores} / \mathrm{mL}^{-1}(2000$ $\mu \mathrm{L})$, Trat $3=2.55 \times 10^{7}$ spores $/ \mathrm{mL}^{-1}(3000 \mu \mathrm{L})$ and Trat $4=$ Control (sterile water), TE $6=$ Evaluation time at six days; TE $10=$ Evaluation time at 10 days.

characteristic "sunken black spots" of anthracnose were selected.

\section{Isolation and purification of the pathogen}

Three cuts of approximately $0.5 \mathrm{~cm}$ in length and $0.3 \mathrm{~cm}$ width were performed on healthy and sick tissue of mangoes. Subsequently, the samples were washed with water and liquid soap to remove any possible pesticide residue, and disinfected with $3 \%$ hypochlorite solution for 1 $\mathrm{min}, 90 \%$ alcohol for $1 \mathrm{~min}$ and washed with distilled water. Tissue was left to dry on sterile absorbent paper at room temperature $\left(25 \pm 2{ }^{\circ} \mathrm{C}\right)$ for $3 \mathrm{~min}$. Next, the sample was transferred to a sterile hood and 3 cuts were equidistantly placed in a Petri dish with PDA + antibiotic (Gentamicin, $1 \mathrm{~mL}$ $\mathrm{L}^{-1}$ ), with 10 replicates. Petri dishes were sealed, labeled, kept at $25^{\circ}-30^{\circ} \mathrm{C}$ for $168 \mathrm{~h}$. Purification of the isolates was performed by monoconidial cultures in PDA (Bioxon + antibiotic), which then were preserved at 4 to $6^{\circ} \mathrm{C}$.

\section{Morphocultural identification of the pathogen}

Identification was performed with a microscope using the DinoCapture 2.0 software (Dino-lite, 2020). Based on colony characteristics (color and shape), conidia (color, length, and width; 100 conidia were analyzed) with the taxonomic keys 
from Barnett and Hunter (2006) to identify genus and the references of Sutton (1992) for species.

\section{Inoculum acquisition and conservation using suspension in sterile distilled water}

An explant with $0.5 \mathrm{~cm}$ diameter was taken and placed in a previously sterilized mortar containing $20 \mathrm{~mL}$ of sterile distilled water. Subsequently, the sample was macerated, and spores were counted from the suspension using a Neubauer chamber.

\section{Pathogenicity tests}

Healthy fruits were inoculated by puncturing and sprinkle a given spore suspension (i.e., treatments) using a dropper (1000, 2000 and $3000 \mu \mathrm{L}$ ); with a control (sterile water), using 10 replicates per treatment and mango cultivar with 5 maturity degrees.

\section{Evaluation of severity (\%)}

Percent damage severity caused by $C$. gloeosporioides in mangoes was examined at day 6 and 10 after treatment using a millimetric sheet.

\section{Experimental design}

A complete random factorial design of three factors was used, where: factor A stands for mango cultivars (Tommy Atkins and Ataulfo), factor B is treatments and factor $C$ stands for times of evaluation (at day 6 and 10). Data was analyzed by Turkey test to 0.01 of significance $(\alpha=0.01)$, using the statistical software SAS 9.1 (SAS 2002; versión 9.1, SAS Institute, Cary, North Carolina, USA).

\section{Conclusion}

Mango cultivars Ataulfo and Tommy Atkins with 5 maturity degrees showed a natural resistance from 80.00 to $93.67 \%$ to anthracnose (C. gloeosporioides). They are considered to a certain extent as resistant. The need for strategies for the protection of crops, environment and people leads us to investigate disease control methods. The use of resistant cultivars is the main one. In addition, it is advantageous for the producer because the cost for disease control it would be less.

\section{References}

Abd-Alla M, Wafaa M (2010) New Safe Methods for Controlling Anthracnose Disease of Mango (Mangifera indica L.) Fruits Caused by Colletotrichum gloeosporioides (Penz.). Journal of American Science. 8(8): 361-367

Agrios GN (2005) Fitopatología, 2da edición. México, Limusa, p. 952.

Ahmad T, Wang J, Zheng $\mathrm{Y}$, Mugizi AE, Moosa A, Chengrong $\mathrm{N}$, Liu $Y$ (2021) First record of Colletotrichum alienum Causing postharvest Anthracnose disease of mango fruit in China. Plant disease. doi: 10.1094/PDIS-09-20-2074-PDN

Almada-Ruiz E, Martínez-Téllez MÁ, Hernández-Álamos MM, Vallejo $S$, Primo-Yúfera $E$, Vargas-Arispuro I (2003) Fungicidal potential of methoxylated flavones from citrus for in vitro control of Colletotrichum gloeosporioides, causal agent of anthracnose disease in tropical fruits. Pest Management Science. 59(11): 1245-1249.

Álvarez E, Mejía J, Llano G, Loke J (2006) Characterization of Colletotrichum gloeosporioides, causal agent of anthracnose in soursop (Annona muricata) in Valle del
Cauca. Poster: International Center for Tropical Agriculture (CIAT).

Andrade EM, Uesugi CH, Ueno B, Ferreira MASV (2007) Caracterização morfocultural e molecular de isolados de Colletotrichum gloeosporioides patogênicos ao mamoeiro. Fitopatologia Brasileira. 32(1): 21-31

Arauz LF (2000) Mango anthracnose: Economic impact and current options for integrated management. Plant Dis. 84: 600-611.

Bailey AJ, Jeger JM (1992) Colletotrichum: biology, pathology and control. British Society for Plant Pathology. CAB. International. p. 388.

Barnett LH, Hunter BB (2006) Illustrate genera of imperfect fungi. Minnesota. The American Phytopathology Society Press. p. 200-220.

Barquero Q, Marcia P, Natalia A, Arauz LF (2013) Presencia de Colletotrichum acutatum y Colletotrichum gloeosporioides en helecho hoja de cuero, limón criollo, papaya, carambola y mango en Costa rica y Florida (Estados Unidos). Agronomía Costarricense. 37(1): 23-38

Bustamante S (2006) Estudio preliminar para la identificación de patrones de expresión génica del hongo Colletotrichum gloeosporioides Var. Alateae expuesto a diferentes estímulos utilizando "DD RT-PCR". Bogotá D.C. Universidad Nacional de Colombia.

Canno PF, Damm U, Johnston PR, Weir BS (2012) Colletotrichum - current status and future directions. Stud Mycol. 73 (1): 181-213.

Chen H, Ma Y, Zhang WF, Ma T, Wu HX (2015) Molecular phylogeny of Colletotrichum (Sordariomycetes: Glomerellaceae) inferred from multiple gene sequences. Genet Mol Res. 14(4): 13649-13662.

Chowdhury M, Rahim M (2010) Integrated Crop Management to Control Anthracnose (Colletotrichum gloeosporioides) of Mango. Journal of Agriculture \& Rural Development, 7(1).

Chung WH, Ishii H, Nishimura K, Fukaya M, Yano K, Kajitani Y (2006) Fungicide Sensitivity and phylogenetic relationship of anthracnose fungi isolated from various fruit crops in Japan. Plant Dis. 90(4): 506-512.

Dean R, Van Kan JAL, Pretorius ZA, Hammond-Kosack KE, Di Pietro A, Spanu PD, Rudd JJ, Dickman M, Kahmann R, Ellis J, Foster GD (2012) The Top 10 fungal pathogens in molecular plant pathology. Molecular Plant Pathology. 13: 414-430.

Dino-lite (2020) DinoCapture 2.0: microscope imaging software. 2020. https://www.dinolite.us/en/dinocapture/

FAOSTAT (2020) Food and Agriculture Organization of the United Nations. Data on food and agriculture. http://www.fao.org/faostat/es/\#home

Fitzell RD, Peak CM, Darnell RE (1984) A model for estimating infection levels of anthracnose disease of mango. Annals of Applied Biology. 104: 451-458.

Gutiérrez-Alonso, JG, Gutiérrez-Alonso $O$, Nieto-Angel D, Téliz-Ortiz D, Zavaleta-Mejía E, Delgadillo-Sánchez F, Vaquera-Huerta H (2003) Resistencia a benomil y tiabendazol en aislamientos de Colletotrichum gloeosporioides (Penz.) Penz. y Sacc. obtenidos de Mango (Mangifera indica L.) en cinco regiones de México. Revista Mexicana de Fitopatología. 21: 260-266.

Hu MJ, Grabke A, Schnabel G (2015) Investigation of the Colletotrichum gloeosporioides species complex causing peach anthracnose in South Carolina. Plant Dis. 99: 797805. 
Jeffries P, Dodd JC, Jeger MJ, Plumbley RA (1990) The biology and control of Colletotrichum species on tropical fruit crops. Plant Pathology. 39(3): $34-366$.

Johnson GI, Muirhead IF, Rappel LM (1989) Mango post harvest disease control: a review of research in Australia, Malaysia and Thailand, ASEAN Fd. J. 4: 139-141.

Lei $Y$, Tang XB, Jayawardena RS, Yan JY, Wang XD, Liu M (2016) Identification and characterization of Colletotrichum species causing grape ripe rot in southern China. Mycosphere. 7(8): 1177-1191.

León GA (2007) Control de Plagas y enfermedades en los Cultivos. Grupo Latinos Editores, México, D.F

López-Vásquez JM, Castaño-Zapata J (2010) Management of mango anthracnose [Glomerella cingulata (Stoneman) Spauld. \& H. Schrenk] in post-harvest. Agronomía. 18(1): 47-57.

Mignouna HD, Abang MM, Green KR, Asiedu R (2001) Inheritance of resistance in water yam (Dioscorea alata) to anthracnose (Colletotrichum gloeosporioides). Theor Appl Genet. 103: 52-55.

Montero V, Morales J, González M, Anaya J, Corona T, Gálvez A (2010) Diversidad genética, patogénica y morfológica del hongo Colletotrichum gloeosporioides (Penz.) de Michoacán, México. Revista Mexicana de Ciencias Agrícolas. 1(2): 157-172.

Muirhead IF, Grattidge R (1984) Post harvest diseases of mango-the Queensland experience, in: Proceedings First Australian Mango Research Workshop Cairns, CSIRO, Queensland, Melbourne. pp. 284-252.

Muñoz C, Gómez L, Umaña G (2003) Caracterización morfológica y bioquímica de aislamientos de Colletotrichum spp. y su patogenicidad en mango (Mangifera indica L.). Tecnología en Marcha. 16(1): 55-65.

Nawab A, Alam F, Hasnain A (2017) Mango kernel starch as a novel edible coating for enhancing shelf- life of tomato (Solanum lycopersicum) fruit. International Journal of Biological Macromolecules. 103: 581-586.

Ngw (2020) Heraldry of the world. What is salicylic acid and in what products is it present?

Ningthoujam DS, Sanasam S, Tamreihao K, Nimaichand S (2009) Antagonistic activities of local actinomycete isolates against rice fungal pathogens. Afr J Microbiol Res. 3: 737742.

O'Connell RJ, Thon MR, Hacquard S, Amyotte SG, Kleemann J, Torres MF, Damm U, Buiate EA, Epstein L, Alkan N, Altmuller J, Alvarado Balderrama L, Bauser CA, Becker C, Birren BW, Chen Z, Choi J, Crouch JA, Duvick JP, Farman MA, Gan $P$, Heiman $D$, Henrissat $B$, Howard RJ, Kabbage $M$, Koch C, Kracher B, Kubo Y, Law AD, Lebrun M-H, Lee $Y-H$, Miyara I, Moore N, Neumann U, Nordstrom K, Panaccione DG, Panstruga R, Place $M$, Proctor RH, Prusky D, Rech $G$, Reinhardt R, Rollins JA, Rounsley S, Schardl CL, Schwartz DC, Shenoy N, Shirasu K, Sikhakolli UR, Stuber K, Sukno SA, Sweigard JA, Takano Y, Takahara H, Trail F, van der Does HC, Voll LM, Will I, Young S, Zeng $Q$, Zhang J, Zhou $S$, Dickman MB, Schulze-Lefert $P$, Ver Loren van Themaat $E$, Ma L J, Vaillancourt LJ (2012) Lifestyle transitions in plant pathogenic Colletotrichum fungi deciphered by genome and transcriptome analyses. Nat Genet. 44: 1060-1065.

Onyeka TJ, Petro D, Ano G, Etienne S, Ruben S (2006) Resistance in water yam (Dioscorea alata) cultivars in the French West Indies to anthracnose disease based on tissue culture-derived whole-plant assay. Plant Pathol. 55: 671678.
Orlando R, Campo AR, Fernández M, Narváez E (2013) Evaluación de la resistencia de poblaciones de maracuya amarillo (Passiflora edulis f. flavicarpa. Degener) a la antracnosis (Colletotrichum C. gloeosporioides Penz). Fitopatologia Colombiana. 37: 39-42.

Padrón J (1991) Elementos de Fisiología Vegetal. Editorial Pueblo y Educación Ciudad de la Habana. p. 58-59.

Páez A (2003) Tecnologías sostenibles para el manejo de la antracnosis en papaya y mango. Boletín Técnico $\mathrm{N}^{\circ} 8$. CORPOICA. pp. 1-18.

Pérez LM, Baquero MJ, Beltran JD (2003) Caracterización morfológica y patogénica de Colletotrichum spp. como agente causal de la antracnosis en ñame Dioscorea sp. Rev Col Biotecnol. 24-35.

Ploetz RC (1994) Anthracnose. In: R.C. Ploetz GA, Zentmyer WT, Nishijima KG, Rohrbach and H D. Ohr (eds). Compendium of tropical fruit diseases. APS Press. The American Phytopathological Society, St. Paul, Minnesota, USA. pp. 35-36.

Ploetz RC (2008) Antracnosis en mango: Manejo de la enfermedad más importante pre y postcosecha.

Prusky D, Freeman S, Dickman MB (2000) Colletotrichum. Host specificity, pathology, and host-pathogen interaction. APS Press, The American Phytopathological Society. St. Paul, Minnesota, USA. pp. 393.

Purnachandra RM, Saritha KV (2013) Potential Applications of 'King of Fruits' (Mango). Indo-Am J Pharm Res. 3(9): 7155-7159.

Sangchote S (1991) Botryodiplodia stem end rot of mango and its control. Acta Hort. 291: 296-303.

Sangeetha CG, Racal RD (2008) Nutritional studies of Colletotrichum_gloeosporioides (Penz.) Penz. And Sacc. The Incitant of Mango Anthracnose. World Journal of Agricultural Sciences. 4(6): 717-720.

SAS Institute (2002) The SAS System for Windows, Release 9.1. SAS, Institute, Cary N. C. U.S.A.

Smooth JJ, Segall RH (1963) Hot water as a post harvest control of mango anthracnose. Plant Dis. Rep. 47: 739-742.

Sutton BC (1992) The genus Glomerella and pathogenic variation among Colletotrichum species isolated from strawberry. Plant disease. 74: 69-76.

Sutton BC (1980) The Coelomycetes: Fungi Imperfecti with Pycnidia, Acervuli and Stromata. Commonwealth Mycological Institute, Kew, UK. 1980. pp. 1-696.

Tandon IN, Singh BB (1968) Control of mango anthracnose by fungicides. Indian Phytopathol. 21: 212-216.

Than PP, Jeewon R, Hyde KD, Pongsupasamit $S$, Mongkolporn O, Taylor PWJ (2008) Characterization and pathogenicity of Colletotrichum species associated with anthracnose on chilli (Capsicum spp.) in Thailand. Plant Pathology. 57(3): 562-572.

Tozze JHJ, Mello MBA, Massola JNS (2006) Caracterização morfológica e fisiológica de isolados de Colletotrichum sp. causadores de antracnose em solanáceas. Summa Phytopathologica, 32(1): 71-79.

Trinidad-Ángel E, Ascencio-Valle FJ, Armando UJ, RagazzoSanchez JA, Calderon-Santoyo M, Baustista RPU (2007) Identificación y caracterización de Colletotrichum spp. Causante de antracnosis en aguacate Nayarit, México. Revista Mexicana De Ciencias Agrícolas. (19): 953-3964

Valdéz L, Calero D, Gómez A, Carballo M, Capote M, González I, Alvarez J, Rohde W (2017) Characterization morphological, cultural and pathogenic of isolated Colletotrichum sp. anthracnose producing in mango 
(Mangifera indica L.). La Granja: Journal of Life Sciences. 26(2): 38-51.

Vega-Piña A (2006) Principales Enfermedades del Mango. In: Vazquez-Valdivia V, Pérez-Barraza MH (Eds.), El Cultivo del Mango: principios y tecnología de producción. INIFAP, Santiago Ixcuintla, Nayarit, México, pp. 235-238.

Villanueva RA, Soriano E, Anguiano A, Mora-Aguilera A, Teliz D (2006) Patogénesis de la antracnosis (Colletotrichum fragariae) en frutos de chirimoya. Agrociencia. 40: 773782.

Wharton PS, Diéguez-Uribeondo J (2004) The biology of Colletotrichum acutatum An. Jard. Bot. Madr., 61(1): 3-22.

$\mathrm{Wu} \mathrm{CJ}$, Chen HK, Ni HF (2020) Identification and characterization of Colletotrichum species associated with mango anthracnose in Taiwan. Eur J Plant Pathol. 157: 115.

Xiao CL, MacKenzie SJ, Legard DE (2004) Genetic and pathogenic analyses of Colletotrichum gloeosporioides isolates from strawberry and noncultivated host. Phytopathology. 94: 446-453.

Zainuri JDC, Wearing AH, Coates L, Terry L (2001) Effects of phosphonate and salicylic acid treatments on anthracnose disease development and ripening of 'Kensigtown Pride' mango fruit. Aust J Exp Agric. 41: 805-813.

Zhou Y, Zhang L, Zeng K (2016) Efficacy of Pichia membranaefaciens combine with chitosan against Colletotricum gloeosporioides in citrus fruits and possible modes of action. Biological Control. 96: 39 -47. 